DePauw University

Scholarly and Creative Work from DePauw University

3-12-2019

\title{
Consumer Choice and Beads in Fugitive Slave Villages in Nineteenth-Century Kenya
}

Lydia Wilson Marshall

DePauw University, lydiamarshall@depauw.edu

Follow this and additional works at: https://scholarship.depauw.edu/socanth_facpubs

Part of the Archaeological Anthropology Commons

\section{Recommended Citation}

Marshall, L.W. Int J Histor Archaeol (2019) 23: 103. https://doi.org/10.1007/s10761-018-0457-2 This is a post-peer-review, pre-copyedit version of an article published in International Journal of Historical Archaeology. The final authenticated version is available online at: https://doi.org/10.1007/ s10761-018-0457-2

This Article is brought to you for free and open access by the Sociology \& Anthropology at Scholarly and Creative Work from DePauw University. It has been accepted for inclusion in Sociology \& Anthropology Faculty publications by an authorized administrator of Scholarly and Creative Work from DePauw University. 
Article Title: Consumer Choice and Beads in Fugitive Slave Villages in Nineteenth-Century Kenya

Author: Lydia Wilson Marshall ${ }^{1}$

Suggested Running Head: Consumer Choice and Beads in Fugitive Slave Villages in Nineteenth-Century Kenya

\section{Mailing Address:}

Lydia Wilson Marshall

Department of Sociology and Anthropology

100 E. Seminary Street

DePauw University

Greencastle, IN, USA 46135

Office Phone: 765-658-4508

Fax: 765-658-4553

${ }^{1}$ Department of Sociology and Anthropology, DePauw University, Greencastle, Indiana, USA 


\begin{abstract}
This study analyzes the consumption of European glass beads at two fugitive slave villages in nineteenth-century Kenya, Koromio and Makoroboi. The consumer choices of Koromio and Makoroboi residents reveal a strategic and symbolic material language. Specifically, the interhousehold distribution of European glass beads reflects considerable variation in the performance of female identity. This distribution suggests varying norms of feminine adornment. Some of these norms likely originated in runaways' natal communities; others may have developed during enslavement. The variability in adornment practices additionally points to women's improvisation amid shifting gender relations in these nascent fugitive slave communities.
\end{abstract}

\title{
Keywords
}

Consumption, beads, gender, runaway slaves 


\section{Introduction}

In coastal Kenya, the 1840s fugitive slave settlement Koromio perched atop steep hills overlooking Kilifi Bay, approximately 60 meters below. The 1880s fugitive slave village Makoroboi sat tucked in an oxbow of the Kavuluni River, which surrounded it on three sides. These natural defenses align with landscape patterns observed at Maroon (that is, runaway slave) settlements in the Americas, where refugees from slavery often sought isolation as a means of protection from re-enslavement (e.g., Agorsah 1995: 227, 2001: 3, 2003: 737; La Rosa Corzo 2003: 225). Yet, Maroon research in the Americas has also consistently demonstrated such refugees' connections to wider global networks of objects and ideas (e.g., Orser 1996). Similarly, at Koromio, seventy four glass beads and one carnelian bead were recovered in domestic contexts from three houses (see Tables 1, 2, and 3). At Makoroboi, where imported goods were generally much rarer, twenty one glass beads and one cast pewter bead were recovered in association with one of the two houses excavated (see Table 4). In analyzing these assemblages, this article advances two claims. First, the selection and use of such ornaments by runaway slaves represent meaningful and intentional consumer choices, rather than only forces of market access and economic standing. Second, the consumption of beads at Koromio and Makoroboi was used in the performance of female identity at these settlements. These varied performances were shaped by the norms of residents' diverse natal communities as well as customs encountered during enslavement; they additionally reflect women's own strategic improvisation in these nascent groups.

\section{Slavery, Marronage, and Bead Consumption in Nineteenth-Century Coastal Kenya}


In the 1800s, Oman controlled much of the Swahili Coast - a strip of land consisting primarily of the coastal regions of present-day Kenya and Tanzania, extending in the north to southern Somalia and in the south to northern Mozambique. While trade in enslaved captives has a time-deep history in Eastern Africa, extending back at least 2,000 years (Beachey 1976: 3), the Omani Sultanate faced increasing British pressure against the overseas slave trade as the nineteenth century progressed. The export of enslaved captives became difficult at this time, but the export of crops produced by enslaved workers remained "legitimate." As external slave markets collapsed, Omani colonists and local Swahili elites reshaped the coast from a crossroads of trade to a center of commercial agricultural production. Enslaved captives came from a variety of inland and hinterland areas, including the territory around Lake Nyasa (Lake Malawi), some $700 \mathrm{~km}$ to the southeast. Indeed, nineteenth century Swahili slaveholders often used Wanyasa (people of the Lake Nyasa area, Swahili, pl.) as a generic term for all peoples of slave ancestry (Cooper 1997:120). Nevertheless, groups much more proximate to the Swahili Coast also faced a considerable risk of enslavement (e.g., Kusimba 2015).

Ironically, the collapse of external slave markets prompted the intensification of largescale, cash-crop agriculture on the coast and a subsequent upsurge in the local slave trade in the mid-nineteenth century (Glassman 1995: 81; Sheriff 1985: 169, 1987: 60). Chief among the commodities grown were cloves (Zanzibar and Pemba Islands), millet (Malindi), and coconuts (Mombasa), though more sporadic production of maize, rice, and sugarcane also occurred (Cooper 1997: 181). The development of large-scale commercial agriculture transformed the nature of enslavement on the Swahili Coast, and its increasing brutality prompted rising numbers of enslaved people to abscond. In coastal hinterland areas, some runaways settled at European mission stations, others joined free indigenous communities, and still others formed independent 
settlements. In Swahili, runaway slaves were known as watoro. In 2007-2008, I excavated two watoro settlements, the 1840 s settlement Koromio and the 1880 s settlement Makoroboi, which was called "Fuladoyo" in missionary correspondence. I here adopt the settlement name used and remembered by current site inhabitants. Makoroboi is a Swahili pluralization of "crew-boy" and references those in the service of Europeans (Sacleux 1939: 440); this place name reflects the close relationship between Makoroboi residents and European missionaries. I also excavated Amwathoya, a free indigenous Giriama settlement contemporaneous with and close to Makoroboi, for comparative data (Figure 1).

At Koromio, archaeological investigations identified three wattle-and-daub (that is, earthen) houses. Each structure yielded a distinct bead assemblage, with very little overlap in the varieties represented (Tables 1, 2, and 3). At the 1880s runaway slave settlement Makoroboi, twenty two beads were identified; all such ornaments were recovered at only one of the two houses excavated (Table 4). The bead classification detailed in Tables 1 through 4 includes both international standard measures (Beck 1927; Kidd and Kidd 1970; Karklins 1985) and historical Eastern African terms (Karklins 1992). I have completed more formal and extensive typological analysis of the recovered bead varieties elsewhere (Marshall 2011: 242-293, 2012a).

By the mid-nineteenth century, most beads imported to Eastern Africa were of European origin. As the century drew to a close, drawn beads dominated over hand-wound varieties, reflecting the increasing mass production and industrialization of Europe's bead industry (Marshall 2012a: 197-198). Koromio’s Structure 1 yielded mostly drawn white, light blue, green, and scarlet-on-white beads (Table 1). Drawn white beads, here classified as hafti, were called a variety of regional names in nineteenth-century Eastern Africa (e.g., Stanley 1872: 24; Burton 1860: 530). Such ornaments were the most numerous bead type found at Koromio as a whole, 
and their popularity is also reflected in their abundance in other eighteenth- and nineteenthcentury assemblages along the Eastern African coast (Kirkman 1974: 139-140; Marshall 2012a: 193). Compound scarlet-on-white drawn glass beads were typically of Venetian origin and possessed strong appeal not only in Eastern Africa but also across the continent as a whole (Karkins 1992: 53). This variety's popularity is reflected in local idiom. Scarlet-on-white beads were called "kimara-phamba (food-finishers) because a man will part with his dinner to obtain them and kifunjyá-mji (town-breakers), because the women will ruin themselves and their husbands for them" (Burton 1860: 113). They are here classified by their most common local name, simsim (alternately samisami), meaning red ant or red bead (Burton 1860: 113; Stanley 1872: 177). However, other bead types recovered at Structure 1, particularly the drawn green beads, were neither popular nor expensive in the mid-nineteenth century (Burton 1860: 531).

Structure 2's bead assemblage was very different from Structure 1's, despite the close proximity of the two houses. Most prominent in the collection are drawn aqua and turquoise-onwhite beads as well as wound white and green glass beads (Table 1). None of these types are among the most popular varieties recorded in historical documents (Burton 1860; Harding 1962; Stanley 1972) or recovered at other nineteenth-century Eastern Africa sites (e.g., Kirkman 1974). The aqua beads are here classified as langiyo (Burton 1860: 530; Stanley 1872: 721) and were recovered in a smaller "knitting bead" size with an average diameter of $2.0 \mathrm{~mm}$ (Marshall 2011: 267), one millimeter or more smaller than most other varieties found at Koromio. The other bead types distinguishing this assemblage, including two spherical wound white beads and drawn turquoise-on-white beads, have no clear historical name. The number of bead varieties available in nineteenth-century Eastern Africa numbered in the hundreds (Burton 1860:113), and only dozens of historical names were ever recorded. These bead types' absence in historical 
documents is not surprising, but it nonetheless shows that Koromio inhabitants were not consuming only the most widely popular varieties.

At Structure 2, two ellipsoid wound white beads were also recovered. This bead type, locally known as sungomaji or sugomazzi and often called "pigeon egg beads" elsewhere in the world (Stanley 1872: 24, 249), most strongly distinguishes Structure 3's bead assemblage. Structure 3 yielded few beads compared to other structures at the site, but its assemblage included a proportionally significant number of sungomaji beads in white and bright blue, these beads' most typical colors in Eastern Africa (Burton 1860: 530). These beads' worth and popularity varied widely in the region depending on local taste. For example, Henry Stanley remarked, "the egg (sungomazzi) beads, though valuable in Ujiji and Uguhha, would be refused in all other countries" (1872: 24). These beads' relative abundance at Structure 3 suggests a partiality for the bead type in that household, though they were apparently less popular with other Koromio inhabitants.

At Makoroboi, no beads were recovered at the second house we excavated; the entire 22bead site assemblage derives from domestic contexts at Structure 1. Despite the settlements' close proximity and overlapping occupation dates, Makoroboi's bead assemblage is less than one percent the size of the assemblage from the free Giriama homestead site Amwathoya, where nearly 4,000 beads were recovered. Makoroboi's bead assemblage contrasts with Awmathoya's not only in its diminutive size but also in the types of beads recovered. Less than half of the specimens found at Makoroboi represent types also identified at Amwathoya. Indeed, the most common variety of bead found at Makoroboi, drawn translucent navy blue short barrels, was not recovered at all at Amwathoya. The watoro site Makoroboi also yielded a wound oblate of identical translucent navy glass. 


\section{Understanding Consumer Choice}

A central claim of this article is that the bead assemblages recovered at Koromio and Makoroboi represent meaningful and intentional consumer choices, rather than simply forces of market access and economic standing. For the past thirty years, consumer choice and consumption models have helped archaeologists understand how the objects that people acquire both reflect and help to shape social self-creation-including not only class, but also gender and cultural identities (Cook et al. 1996; Fitts 1999; Miller 1987; Rotman 2009; Spencer-Wood 1996; Wall 1991, 1994). Spencer-Wood's (1987a: 1, 4, 10-11) Consumer Choice in Historical Archaeology demonstrated how consumption patterns (particularly of ceramics and fauna) are shaped by socioeconomic status, market access, ethnicity, race, and political status, as well as household size, composition, and life cycle. With archaeology's symbolic turn and the greater acceptance of post-processual approaches in the 1990s, some scholars critiqued a perceived overemphasis on socioeconomic factors in early consumer choice research. Beaudry (1999: 119), for example, noted that consumer choice research was rarely able to tease apart the consumption of different household members. Certainly, it is often impossible to determine which individuals living at a site bought which items deposited in the archaeological record. Other archaeologists have critiqued early consumer choice analyses for simply confirming socioeconomic data already available in written documents (Cook et al. 1996: 52; Beaudry 1999: 119), though we should note that early studies sometimes identified discrepancies between historical and archaeological indicators of class (e.g., Garrow 1987: 230). 
While fewer studies have aligned themselves explicitly with the consumer choice school since the early 1990s (Orser 2004: 165), interest in consumption, particularly its symbolic aspects, has only grown. Cook et al. (1996) suggested that an increased focus on agency could help archaeologists recognize the symbolic implications of consumption choices. Individuals consume objects, they argued, to achieve specific social goals. For example, the consumption and use of transfer-printed tea wares helped hivernant Metis women advertise their suitability as marriage partners to European-American traders (Burley 1989, cited in Cook et al. 1996: 58). As Mullins notes, "Consumption defined this way revolves around the acquisition of things to confirm, display, accent, mask, and imagine who we are and who we wish to be, which breaks from seeing consumption as a largely reflective process that instrumentally displays social status, evokes ethnicity, exhibits gender, or confirms other essential identities" (2011: 135).

Wurst and McGuire (1999: 192,196) conversely argued against the fetishization of agency and the individual; from a Marxian perspective, they urged greater archaeological focus on production rather than consumption. Wurst and McGuire maintained that consumer choice models disregard how economic necessity curtails and shapes consumption. They thus argued that consumer choice approaches help to mask deep social inequalities and are ineffective tools for archaeologists wishing to address gender, class, and racial disparities (Wurst and McGuire 1999: 198). Finally, Wurst and McGuire cautioned against the consumer choice model's tendency to naturalize the consumption expectations and patterns of Western capitalism.

However, economic constraints on consumption choices were identified even in the very earliest consumer choice studies (e.g., Branstner and Martin 1987: 317; Garrow 1987: 229, Heberling 1987: 214; Shepard 1987: 192; Singer 1987: 94; Spencer-Wood and Heberling 1987: 73-74). Additionally, while Wurst and McGuire (1999: 197) argued that "modern consumption 
is not a global phenomenon," archaeologists have paid increasing attention in recent years to how indigenous people in so-called global peripheries consumed mass-produced European and American goods on their own terms and used them for their own purposes (e.g., Croucher 2011; Gijanto 2011; Harrison 2007; Marshall 2012a; Richard 2013). The mass-production revolution, which archaeologists have long recognized fundamentally changed Europeans' and European Americans' relationships with objects (Mullins 2011: 139-140), similarly affected people living in more far flung geographic locales in the eighteenth and nineteenth centuries-including runaway slaves in coastal Kenya.

Indeed, even the harshest critics of the consumer choice school recognize that "people have always consumed" (Wurst and McGuire 1999: 196). Mullins (2011: 135) recently argued that consumption provides a flexible theoretical model that can be productively applied in a diverse range of archaeological settings. For example, while "conspicuous consumption" studies have established the role of goods in the performance of elite status in both historical and prehistoric archaeology, recent work suggests that consumption by non-elites could play a similar role in asserting claims to a favorable social position and class (Galle 2010; Mullins 2001; Pezzarossi 2014). Through the selection, consumption, and use of particular European glass bead types, Koromio and Makoroboi residents created and communicated a variety of social, gendered, and cultural identities. My theoretical approach aligns with Cook et al's (1996) call to see shopping as "meaningful action," as well as more recent studies highlighting symbolic aspects of consumption (e.g., Mullins 2001, 2011).

\section{Marronage, Isolation, and Connection}


This article's analysis focuses on the performance of female identity through bead adornment at Koromio and Makoroboi. While women have been a primary focus of the consumer choice model since the 1980s (Singer 1987: 94; Spencer-Wood 1984, 1987b: 336-338, 1991: 250; Klein 1991; Wall 1991, 1994), some scholars have argued against the model's applicability to economically depressed populations (e.g., Wurst and McGuire 1999: 198). Put simply, could poor people participate in the consumption of mass-produced goods to such an extent that their "choices" are particularly interpretively meaningful? Do these choices reflect performances of aspirational or actual identities? Or, did poor people simply buy what they could afford and what was available to them through the market system? Such concerns are certainly relevant to the analysis of consumption at nineteenth-century fugitive slave settlements in Kenya.

Both popular and academic understandings of escaped slave or Maroon communities tend to emphasize their isolation, poverty, and self-sufficiency. For example, refugees from slavery who retreated into the Great Dismal Swamp of North Carolina and Virginia settled on interior "islands" of dry ground largely cut off from colonial society. Archaeological excavations have uncovered reworked lithic tools and numerous postholes in the swamp but few mass-produced trade goods. This material paucity suggests that residents had little access to objects from the outside world, instead primarily sustaining themselves with natural materials found within the swamp (Sayers 2007: 155, 2014: 116). Isolation from colonial slave-holding society was an important survival strategy for Maroons facing the continuing threat of re-enslavement. Escaped slaves in many different world regions settled in ecologically marginal, distant, elevated, fortified, or otherwise foreboding landscapes (e.g., Agorsah 1995: 227, 2001: 3, 2003: 737; La Rosa Corzo 2003: 225). Such landscapes, coupled with the often-faint material imprint of 
Maroon sites, have sometimes complicated archaeological investigation (e.g., Baram 2008: 6; Chowdhury 2003: 20; Orser 1998: 71; Weik 2004: 42).

Nonetheless, archaeologists increasingly recognize that many Maroon groups were not isolated from the world at large. In prior research (Marshall 2011, 2012b), I have argued that isolation from and connection to outsiders could be complementary survival tactics. For the best chance of success, Maroons needed to isolate themselves from some outsiders but connect with others. Black Seminoles in Florida (Weik 2009) and Palmares residents in Brazil (Allen 1998) both forged strong connections with local Native American groups. Ties were also sometimes formed between refugees from slavery and European missionaries or colonists. Maroons in Jamaica famously signed treaties with their British antagonists, agreeing to return new runaways who came to their settlements and even participate in the suppression of slave revolts in return for the right to self-determination (Bilby 1997). The material cultural residues recovered at Maroon sites frequently reflect such external connections. For example, the abundance of European trade goods at Jamaican (Agorsah 1997: 289), Floridian (Deagan and Landers 1999: 273), and Brazilian Maroon sites (Orser 2005: 91) linked resident refugees to wider global networks of objects and ideas (see also Orser 1996). Archaeological remains and historical records suggest that fugitive slaves in Kenya were similarly integrated into broader economic and social networks.

Established by the early 1840s, Koromio is one of the first runaway slave villages in Kenya to surface in historical documents. The written record emphasizes the strength of Koromio's external trade connections. In particular, these accounts mention a cattle and ivory market at the settlement where Swahili merchants from the coast were able to access the livestock of Oromo herders and tusks of Waata hunters through watoro intermediaries (Krapf 
1846a; see also Morton 1978). Koromii means bulls in both Oromo and Waata (Stroomer 1987:

347), so the very name of the settlement likely references this market. Abundant faunal remains of cow, goat, and sheep also were recovered at the site. Additional evidence of residents' participation in trade includes a plethora of imported items - especially imported pottery but also including beads, various iron objects, and glass bottles. Koromio residents' particularly close relationship with Waata hunter-gatherers is reflected in European accounts referring to Koromio as a "Dahalo [Waata] place" (Krapf 1846b). Indeed, after the settlement was attacked and razed by Swahili slave owners in December 1848, many survivors integrated into neighboring Waata communities (Krapf 2002: 90; Marshall 2015: 291-292).

The second runaway slave settlement excavated, the 1880s Christian village Makoroboi, similarly maintained close ties with neighboring Giriama indigenes. Indeed, many watoro men eventually married and integrated into neighboring Giriama families (Marshall 2015: 290-291). In addition, Makoroboi residents—-particularly the settlement's leader, convert David Koicultivated relationships with the Anglican Church Missionary Society (Price 1882; Strayer 1973: 238-239). Yet, despite such demonstrably strong social connections, the village appears to have been more economically isolated than Koromio. Very few mass produced imports were recovered during survey and excavation. The town's geography also suggests purposeful isolation (Figure 1); it was situated in thick forest, some 30 kilometers from the coast, and protectively surrounded on three sides by an oxbow in the Kavuluni River. Nonetheless, Makoroboi deposits yielded clear material evidence of access to outside markets, including small amounts of imported pottery, beads, glass, and carved ivory. Neither watoro settlement was cut off from the external world; both maintained social and economic ties that extended beyond their own borders. 


\section{Bead Consumption and Consumer Choice in Nineteenth-century Eastern Africa}

Archaeological remains and historical records suggest that fugitive slaves in Kenya were not only tied to broader international trade networks but also remained discriminating consumers of mass-produced goods, including beads (see also Marshall 2012a). The objects that runaways chose to purchase both reflected and helped to shape their identities. Relative poverty and restricted market access indeed constrained their consumption choices. However, these restrictions do not preclude the possibility that the choices that runaways made within these constraints were socially and symbolically meaningful. The agency and power of nineteenthcentury Eastern African consumers in the global market has been the subject of considerable attention from historian Jeremy Prestholdt (2008). Prestholdt (2008: 77) points out that the consumption patterns of imported goods in Eastern Africa affected international production elsewhere (see also Marshall 2011: 228). Moreover, he argues that consumers "domesticated" imported goods via their own cultural logics and used them toward their own ends; that is, in nineteenth-century Eastern Africa, we see "a deployment of global symbols in the service of local image-making practices" (Prestholdt 2008: 93). Prestholdt recognizes the agency not only of coastal elites but also interior Eastern African groups in their selection and consumption of imported beads (Prestholdt 2008: 63-65).

Glass beads had been imported to Eastern Africa from India for centuries prior to Europeans' arrival in the region (Van der Sleen 1973: 81-82; Carey 1986: 10). Early European explorers and colonists quickly recognized beads' utility in local and regional trade. Such ornaments' diminutive size, easy portability, and potential for extreme profitability made them 
attractive trade objects to Europeans (Dubin 1987: 106). Only cloth held a more important position in the interior Eastern African trade of the nineteenth century (Karklins 1992: 49). Most beads imported to Eastern Africa in the 1800s were mass-produced European specimens. These included a diversity of colors, sizes, and patterns (see Marshall 2012a). Indeed, one explorer reported that 400 distinct bead varieties were available on the Swahili Coast in 1860 (Burton 1860: 113). Between 1859 and 1865, beads made up four percent of total annual imports to Zanzibar (Mann 2000: 43).

Documentary records make very clear how dependent European explorers were on beads as a trade good. After his porter stole five pounds of the expensive scarlet-on-white variety, Henry Stanley lamented, "Beads abstracted! At such a period, when every bead is of more value to me than its bulk in gold or gems" (1878: 379). Equally clear in the archive is Europeans' frustration with their African trade partners' unpredictable and varying preferences for specific bead varieties. Stanley complained, "One tribe preferred white to black beads, brown to yellow, red to green, green to white, and so on" (1872: 23-24). The wide diversity of bead types imported to the region points to the varied tastes of coastal and inland consumers. This variation made it very difficult for explorers to predict which types of beads would be most valued by the groups they would encounter in the interior (Prestholdt 2008: 64).

Bead fashions not only varied geographically but also shifted over time. Joseph Thomson reported, "In one year a tribe goes mad for a particular bead; but the trader having supplied himself with the fashionable article, according to the latest news, might, if his journey was long, arrive to find the fashion changed and his stock just so much unmarketable rubbish" (1881: 35). Stanley and Thomson's frustration importantly underlines Eastern African residents' position as discriminating consumers of European goods. That is, these accounts provide clear evidence of 
Eastern Africans' ability to make consumption choices, however constrained by market access and financial means; they judged certain bead varieties desirable and others undesirable. Burton and fellow explorer John Speke, for example, had to throw out several hundred strands of beads rejected by interior Eastern African groups as unfashionable (Stanley 1872: 24). Given their diffusion across domestic contexts, the beads that I recovered at Koromio and Makoroboi are extremely unlikely to represent such rejects: these beads were scattered throughout several domestic contexts, suggesting occasional loss during everyday use. Indeed, we should not take their deposit as indicating lack of careful curation: Beads are small items that are easily lost. These ornaments also may have been left behind in the sudden and unplanned abandonment of Koromio in 1848 (Morton 1976: 125-129) and of Makoroboi in 1883 (Handford 1885: 167), when each of these villages came under attack by slave owners.

My argument for runaway slaves' agency in bead consumption, however, doesn't simply rest on the broader clout of Eastern Africans as global consumers. Rather, such agency is reflected in the composition of the particular bead assemblages found at the two watoro sites. For example, at Koromio's Structure 1, recovered glass beads included popular and costly varieties, such as white drawn beads and red-on-white compound draw beads (Table 1). Yet, other ornaments found at Structure 1, such as the drawn green beads, were considerably less popular and expensive in the mid-nineteenth century (Burton 1860: 531). These beads' presence alongside the most widely popular and costly varieties suggests that the bead consumption choices of Koromio inhabitants were not dictated solely by market access or financial means. That is, though the inhabitants of Structure 1 could afford more expensive types of beads, they also chose to consume less broadly popular varieties. 
At the 1880s runaway slave settlement Makoroboi, twenty two beads were identified (Table 4). Despite the settlements' close proximity and overlapping occupation dates, Makoroboi's bead assemblage is less than one percent the size of the assemblage from the free Giriama homestead site Amwathoya, where nearly 4,000 beads were recovered. Beads' paucity at Makoroboi is matched by a similar (indeed, greater) scarcity of other types of imported goods, suggesting the watoro village may have been less wealthy or maintained poorer access to regional trade networks than Amwathoya. Only three imported pottery sherds were recovered at Makoroboi. Beads' comparative abundance suggests that Makoroboi residents prioritized bead consumption while negotiating the constraints of their limited economic ability to engage with outside trade.

Makoroboi's bead assemblage contrasts with Awmathoya's not only in its diminutive size but also in the types of beads recovered. Less than half of the beads recovered at Makoroboi (Table 4) were types also identified at Amwathoya. Indeed, the most common variety of bead found at Makoroboi (drawn translucent navy blue short barrels) was entirely absent at Amwathoya. The same translucent navy glass also distinguished a wound oblate identified at Makoroboi. Given the sites' overlapping dates of occupation and close geographic proximity, completely separate trade connections seem unlikely. The two sites' bead assemblages' dissimilarity from one another instead suggests that Makoroboi and Amwathoya residents preferred different bead types. Importantly, the beads consumed at Makoroboi do not simply replicate the look of Amwathoya beads with cheaper but similar varieties. Rather, the prevalence of translucent navy glass in Makoroboi's assemblage strongly points to a differing aesthetic preference driving consumption at the settlement. Like other consumers in Eastern Africa 
(Prestholdt 2008), runaway slaves at Makoroboi and Koromio were able to navigate constraints on their consumption to make meaningful and active choices.

This article's initial task was to demonstrate the agency of runaway slaves in the selection and use of imported beads in nineteenth-century Kenya. Yet, if, as I have argued, Koromio and Makoroboi residents were active consumers, the larger question still remains: What do their bead consumption choices mean? That is, why did residents select particular types of beads? In the remainder of this article, I argue that the bead assemblages at Makoroboi and Koromio reflect thoughtfully structured performances of femininity. The above assertion may appear initially as a tall order to fill. Not only must we establish women's presence at runaway slave settlements in nineteenth-century Kenya, but we must also analyze female residents' power as consumers in a region and at a time strongly shaped by patriarchal ideals. It is equally necessary to defend my assumption that beads were exclusively or predominantly consumed by women at Koromio and Makoroboi. Only with such an interpretive footing built may we begin to unpack the social and symbolic importance of women's selection and use of imported beads within runaway slave communities.

\section{Women in Enslavement and in Self-Emancipation}

Slavery was a strongly gendered experience in nineteenth-century Eastern Africa. In particular, men had greater opportunity for integration and social advancement under the confines of enslavement. For example, enslaved mafundi, semi-independent skilled urban workers, were exclusively male. Female slaves predominated in plantation agricultural settings, where interaction with coastal elites was typically less frequent. Even on plantations, male 
workers were likely to receive greater instruction in Islam from their owners than were female slaves (Romero Curtin 1983: 869). Such differentiation has led some to argue that enslaved men and women experienced and responded to the cultural norms of Omani and Swahili slave owners (including patronage, patriarchy, Islam, and mercantilism) differently. Some enslaved mafundi pursued dominance over female and junior male dependents and acquired ranked titles in an effort to establish legitimacy as coastal Muslim gentlemen (Glassman 1995: 92). In contrast, slave women were frequently prohibited from veiling, a practice central to claims to a "civilized" and pious female Muslim identity (Deutsch 2006: 67; Fair 1998: 68).

Whether or not they converted to Islam, female slaves on the Swahili Coast were significantly less secluded than many freeborn elite women (Bromber 2007: 122). However, looser restrictions on their physical movement did not translate in any real sense to greater relative power (Deutsch 2007: 129-130). For example, enslaved women rarely selected their marriage partners (McMahon 2015). Female slaves were also generally barred from the types of skilled self-employment (like tailoring, rope-making, or carpentry) that enabled the greater economic and social independence of mafundi (Deustch 2007: 135). Patriarchal norms and structures characterized not only the Swahili Coast but also many of the interior communities in which enslaved captives originated. As Coquery-Vidrovitch put it, whether before or in captivity, enslaved women "always belonged to someone-their lineage, their husband, or their master" (2007: 53). Indeed, male slaves sometimes used patriarchal rhetoric to make claims over their (enslaved) wives and daughters that conflicted with the claims of slave owners (Glassman 1995: 90).

Historical documents provide limited insight into how watoro groups articulated with the larger enslaved community along gender lines. The analysis of runaway slave advertisements in 
the United States suggests that approximately three-fourths of runaways there were male, with young men in their teens and twenties particularly well represented (Franklin and Schweninger 1999: 210-213). In Brazil, at the large and politically complex Maroon polity Palmares, men initially so dominated the population that enslaved and indigenous women were sometimes reportedly kidnapped and brought to the settlement to act as wives or companions (Kent 1965: 170). In Eastern Africa, watoro settlements may have been similarly male heavy. Oral histories of Makoroboi, in particular, strongly indicate a mostly male population (e.g., Ngumbao Iha, interviewed 25 October 2007; Johana Karisa Katenge, interviewed 26 October 2007). Yet, even if they were a distinct minority, women were not absent from Makoroboi. In 1882, missionary William Salter Price wrote of his visit to the settlement: "Men and women crowded upon us, each one eager for a [hand] shake, and 'yambo, yambo sana' ['jambo, jambo sana'] greeted us from all sides" (1882: 92). Such oblique historical glances confirm the presence of women at runaway slave settlements, but do little to reveal women's gender expression or the relationship between men and women at the settlement. Consumption patterns of beads can tell us more.

\section{Were Beads 'Female’ Objects? Were Female Runaway Slaves Consumers?}

One repeated complaint about consumer choice models is that it is difficult to differentiate the consumption of different household members (e.g., Beaudry 1999: 119). Rather, the household's consumption forms an archaeological palimpsest. One means by which historical archaeologists in the United States have meaningfully addressed gender is through a consideration of objects specifically produced for, bought by, or marketed to women (e.g., Wall 1999) or men. The material record represents cumulative consumption choices, and it is often 
difficult to differentiate between male and female consumption in the same household on the basis of discard patterns alone. Thus, gendering material objects themselves solves a basic conundrum of the consumer choice model. Yet, while this approach has considerable interpretive utility in U.S. and European contexts, its application in non-Western settings requires more caution. Put simply, just because an object is produced, say, in Europe for women, we may not assume similar gender associations when that object is consumed in other world regions. We must explicitly consider whether or not the European glass beads recovered at fugitive slave settlements in nineteenth-century Kenya may be considered "female" objects—-specifically did refugee women both select and wear the beads we recovered?

The answer to this question is complicated by the cultural plurality of runaway slave settlements themselves. Enslaved people on the Swahili Coast were captured from a variety of inland and hinterland areas through trade routes running north, south, and west. Additionally, individuals born on the coast into slavery or enslaved as small children tended to be more acculturated to Swahili lifeways; those captured and enslaved as adults were more likely to remain rooted in the cultural ethos of their natal communities. As enslaved people varied in their sociocultural orientations and outlooks, we may reasonably anticipate similar variation among watoro. That is, as slaves varied, those who ran away from slavery also likely varied. Then, how can we evaluate whether or not beads were "female" objects at Koromio or Makoroboi, since all members of such refugee communities may not have shared similar conceptions of gendered consumption?

My argument for linking beads to women at these settlements is rooted in a wider regional pattern. In coastal Swahili society, men typically never wore beads; such ornaments were firmly associated with women and children (Donley-Reid 1990: 49, 51). A similar pattern 
is evident among the indigenous groups neighboring Koromio and Makoroboi in Kenya's central coastal hinterland. I unearthed the most beads — nearly 4,000 — at Amwathoya, a Giriama homestead site contemporaneous with and adjacent to Makoroboi. In an oral historical interview, elder Kang'ombe Nzaro Moka explained that, by wearing beads, "you became a real girl" (interviewed 26 May 2008, translated from the original Giriama by Leonard Mwangala). Moka’s comment explicitly links bead adornment to the performance and reification of a female Giriama identity, as has previous scholarship (e.g., Brantley 1981: 14). Other ethnohistorical accounts and academic analyses point to beads' use in the expression of female identity in many additional agriculturalist, pastoralist, and hunter-gatherer groups in Eastern Africa (e.g., Barrett 1911: 30; Bianco 1991; Gissing 1884: 556; Labelle 2005: 17; Kassam and Megersa 1989; Roberston 1997 : 31-32). This is not to say that men in Eastern Africa never wore beads, but rather that previous research points to a much stronger association between such ornaments and women.

The association between women and beads that we see on the Swahili Coast (where watoro were formerly enslaved) and in the coastal hinterland (where watoro formed independent settlements) is also apparent farther south, in the Lake Nyasa region, where many enslaved captives originated. David Livingstone described what he called a few male dandies in the area wearing beads (Livingstone and Livingstone 1865: 256). But, in general, such ornaments, he noted, were worn by women, who were as discriminating in their taste as consumers elsewhere in Eastern Africa. Livingstone noted, "Fashion is as despotic [here] as it is in London and Paris. The ladies will not wear beads that are out of fashion, however pretty they may be" (Livingstone and Livingstone 1865: 295).

While residents of the watoro settlements Koromio and Makoroboi likely varied in their conception of the relationship between gender identity and bead adornment, a survey of 
ethnohistorical data and previous historical, anthropological, and archaeological research indicates a broad regional affinity between women and beads. This affinity is apparent in many of the communities from which captives originated, in the communities in which they were enslaved, and in the regions in which they settled. Thus, despite the diversity of social and cultural backgrounds that runaway slaves brought with them to freedom in the coastal hinterland, a general link between bead adornment and female identity in the region is clear. This association forms the basis for my analysis of the performance of female identity at Koromio and Makoroboi.

A second complication to address here is the degree of female participation in commerce. Specifically, given the predominance of patriarchy throughout Eastern Africa, may we reasonable assume, even if women wore the beads found at Koromio and Makoroboi, that women likewise selected them? That is, if commerce were controlled by men at these runaway slave villages, wouldn't the bead varieties recovered represent male choice and preference, whether or not women wore the beads that men bought? I find the presumption of a male stranglehold on commerce at Koromio and Makoroboi to be unconvincing. Despite their reduced social standing vis-à-vis male slaves, enslaved women regularly participated in commerce on the Swahili Coast — selling crafts and food stuffs they produced independently or acting as commercial surrogates for their typically more secluded mistresses (Bromber 2007: 119; Deutsch 2007: 133). In post-emancipation contexts, we see formerly enslaved women claiming greater rights in several arenas, for example in selecting marriage partners (McMahon 2015), claiming the once-forbidden veil (Deutsch 2006: 67), and participating more fully in the trade economy (Cooper 1980: 74). We can reasonably expect self-emancipated women would attempt to expand their freedoms along similar lines. In addition, there is no evidence to indicate that female 
runaways would relinquish commercial rights that they had held in captivity. Thus, the beads recovered at Koromio and Makoroboi likely represent ornaments that women both wore and chose.

\section{Performance, Practice, and Innovation}

This study's analysis of bead adornment patterns is rooted in practice theory, in particular Judith Butler's (1990) idea of gender performativity — that gender identities are performed and reified through such performance rather than simply existing a priori. More than simply a passive indication of socioeconomic status or market access, consumption is now recognized by archaeologists as an active part of social self-creation (e.g. Cook et al. 1996; Mullins 2011, Pezzarossi 2014). Following Butler (1990, 1993, 2004), I approach womanhood in Koromio and Makoroboi not as a single, stable thing reflected through cultural practice, but rather as multiple, individual, ongoing, and varied gendered performances.

Many archaeologists have found value in practice theory's emphasis on everyday behavior, individual agency, and the structures that constrain that agency (Bourdieu 1977, 1990; Giddens 1984). One of the most useful concepts for archaeologists has been Pierre Bourdieu's idea of habitus, a type of "embodied history" (Bourdieu 1990: 56). Through habitus, past experience constrains and shapes individuals' current behavior. Thus, one need not be consciously aware of social rules to abide by them. Yet, importantly, practice theory concurrently recognizes individuals' agency. Far from the automatons of functionalist anthropological models, people are recognized in practice theory as improvising within a structure of constraints. Practice theoreticians argue that by analyzing behavioral patterns in the 
archaeological record, we can locate and delineate habitus - the embodied social rules and constraints that subconsciously shape cultural practices.

Despite enthusiastic adoption of habitus, archaeologists have been much less inclined to use (or, indeed, even acknowledge the existence of) other related core concepts from Bourdieu, like doxa, orthodoxy, heterodoxy, and field. Archaeologists' generally flat-footed and truncated theoretical application of Bourdieu has been the subject of critique by Orser. He contends, "Such exclusionary focus [on habitus] presents dispositions as one-dimensional features that have all the characteristics of essentialized whole-cultural traits" (Orser 2004: 141). That is, those archaeological studies that use habitus while ignoring Bourdieu's broader theoretical framework tend to gloss over social divisions and power differentials within societies.

Here, I want to consider the idea of field (Bourdieu and Wacquant 1993: 94-114). To perhaps oversimplify the concept, a field is an arena in which different actors occupy different positions based on their cultural, social, and economic capital. Individuals have more or less influence on the rules governing the field based on characteristics of their position. Bourdieu recognizes the existence of many fields within society—institutional, religious, political, and so on - each governed by its own rules but also interacting with and affected by other fields (Hanks 2005: 74). The concept field is helpful in considering how continuing power differentials shaped the lives of self-emancipated people. Considering the threat of re-enslavement that they negotiated, many newly free people lived in ways still constrained by their reduced position in the social field: In where they chose to live, how they interacted with each other and others, and - yes - how they made consumption choices. Such constraints, not least of market access and economic standing, must be acknowledged in any analysis of their choices as consumers. Yet, the choices that runaways made within these constraints were nonetheless socially and 
symbolically meaningful. Runaways' consumer choices helped to create and communicate a variety of entwined social, gendered, and cultural identities. This article investigates this process through a Butlerian lens.

Judith Butler (1990, 1993, 2004) applied practice theory's emphasis on "doing” in her ambitious analysis of gender identity. In the seminal Gender Trouble (1990), Butler argued cogently against the idea of stable female or male identities. One is a woman, Butler explained, not by virtue of any innate or inborn identity. Rather, one is a woman by virtue of a constant and meticulous performance of womanhood. One is a woman by virtue of how one walks, sits, talks, laughs, cries, adorns one's self, dresses, and so on. Such gendered behavior evokes prior female performances (and associated cultural norms) through what Butler called citationality (1993: 14). And these performances are relentless — they are an "ongoing, discursive practice ... It is ... never possible finally to become a woman ... Gender is the repeated stylization of the body, a set of repeated acts within a highly rigid regulatory framework that congeal over time to produce the appearance of substance, of a natural sort of being” (Butler 1990: 33). Butler argued very persuasively against the idea of natural or static genders through her examination of the perpetual performances needed to sustain such identities.

Archaeologist Rosemary Joyce (2000) has made particularly fruitful use of Butler's performativity theory through her analysis of the development of gender identities in Aztec children (see Perry and Joyce 2001, 2005 for a broader review of Butler's influence on archaeology). Joyce showed how the accumulation of specific types of gendered adornmentincluding labrets, hair treatment, and specific clothing — supported the transition to adult male and female Aztec identities. Public ritual performances likewise facilitated the adoption of manly and womanly identities by their young participants (Perry and Joyce 2001: 66). 


\section{The Consumption of Beads at Runaway Slave Settlements in Nineteenth-Century Coastal Kenya}

Thus far, I have worked to establish that Makoroboi and Koromio residents were active consumers in the global trade of goods and that it was predominantly women who selected and wore the beads found at these sites. Yet, the larger question remains: What do women's varying consumer choices indicate? Why did the beads at Makoroboi so strongly contrast those found at the neighboring Giriama homestead Amwathoya? Why did each structure at Koromio yield a distinctive bead assemblage? I argue that beads were used at Makoroboi and Koromio in the performance of linked gendered and cultural identities. These performances were shaped by adornment practices in runaway slaves' varied natal groups as well as by ideas residents had encountered while enslaved on the Swahili Coast. In addition, the assemblages reflect women's own improvisation and agency in reshaping gendered norms and identities in these nascent communities.

For Joyce, the importance of Aztec adornment practices was the embodiment and performance of identities that they supported. She explains, "[t]he bodies of children were systematically laden with signs of difference in gender, achievement, and status" (Joyce 2000: 480). In nineteenth-century Eastern Africa, the work that beads did to embody a gendered identity is similar; this embodiment was rooted in the performance of female beauty and sexual desirability. Such use of beads is apparent in the Lake Nyasa region from which many captives originated, on the Swahili Coast where they were enslaved, and in the coastal hinterland where runaways settled in free communities. 
When interviewed near the runaway slave site Makoroboi, Giriama elder Kang'ombe Nzaro Moka described a certain bead variety thus: "I heard . . when you wear this type each and every man who will come across you will admire you" (interviewed 26 May 2008, translated from the original Giriama by Leonard Mwangala). While locally made shell beads often had healing connotations for the Giriama, their imported glass counterparts were most often used for beautification (Kang'ombe Nzaro Moka, interviewed 26 May 2008). Similarly, on the Swahili Coast, as late as the 1980s, a string of glass beads around the waist could be worn to provide "husbands [with] added sexual pleasure during intercourse" (Donley-Reid 1990: 51). Such beaded belts are present in ethnohistorical literature on the Swahili Coast as early as the turn of the $20^{\text {th }}$ century; at that time, they were worn by both women and girls beginning in adolescence in order to attract potential husbands (Donley-Reid 1990: 51). Indeed, even though children are reported to have sometimes worn beads on the Swahili Coast, such ornaments often functioned as marking a specifically adult female identity. This association between beads and womanliness extended into some Eastern African interior areas as well: In the Lake Nyasa region, where many enslaved captives originated, David Livingstone observed a coming-of-age ceremony in which the adolescent "girls were dressed in a profusion of beads" (Livingstone and Livingstone 1865: 543).

At Koromio, some of the variability observed between different structures' bead assemblages may be rooted in the beauty norms and adornment practices of runaways' varied natal groups. Unlike their male counterparts, most enslaved women had little means for social advancement in the patriarchal social hierarchy (Glassman 1991: 292; cf. Croucher 2007 on concubinage). Therefore, female slaves may have engaged coastal culture less than their male counterparts (Sunseri 1993: 485). These distinctions in treatment under slavery are very likely to 
have impacted how gender identities were experienced and expressed by both enslaved workers and refugees from slavery. In particular, in comparison to men, enslaved women's gender identities may have been more rooted in the norms of their disparate origin communities than in Swahili culture. That is, female runaways may have had a diverse range of previous "citations" (Butler 1993: 14) of womanhood to draw upon in constructing their gendered performances. These choices may in part be linked to differing habitus of gendered adornment rooted in their origin communities. European explorers in Eastern Africa certainly noted that bead preference often varied by region or cultural group (e.g., Prestholdt 2008: 65).

Of course, while habitus may have shaped the bead consumption of Koromio inhabitants, their consumer choices were additionally constrained by other forces. In particular, their location as runaway slaves in the field of Eastern Africa political and social relations meant that Koromio residents negotiated a constant threat of re-enslavement, which affected their access to markets. Put simply, such refugees could not purchase any bead variety they might like; they were constrained by the merchandise of the Swahili traders who visited their settlement to procure cattle. In addition, some variation between household bead assemblages at Koromio may relate to differences in economic standing. For example, the presence of expensive scarlet-on-white compound beads at Structure 1 and their absence at Structure 2 may indicate unequal access due to unequal household wealth. However, importantly, economic standing cannot alone explain all the variation between the bead assemblages at these structures: Every assemblage included some less popular and less expensive varieties, which were distinct at each household, indicating differing cultural preferences.

Anthropologists in Eastern Africa have long noted a correlation between beauty norms and sociocultural norms. That is, wearing particular beads in a particular formation is not just 
about looking beautiful but also about marking oneself as socially acceptable (Labelle 2005: 17). When women at Koromio chose to adorn themselves with particular varieties of beads, they were expressing linked cultural and gendered identities. Notably, while the bead assemblages recovered at Koromio's structures are strongly distinct, these household differences are not expressed in every material class. For example, imported pottery—the most common type of imported object recovered—varied little between households, everywhere being dominated by coarse Indian redware. Thus, the variation in bead types between Koromio's structures shows the potential greater importance of such ornaments in culturally distinct performances of female identity and female beauty.

It is indeed tempting to link the bead preferences at each structure to specific nineteenthcentury ethnic groups or regions. For example, the pigeon egg beads' dominance at Structure 3 seems to align with Stanley's (1872: 24) observation of this variety's unusual popularity in Ujiji. However, bead preferences often varied village to village within a single region; they also shifted year to year, much to the frustration of European traders and explorers. While I cannot reasonably link Koromio bead preferences to specific ethnicities or origin points, the data nonetheless indicate the lasting influence of different citational practices (Butler 1993: 14) of femininity— that is, different culturally embedded ideas about female adornment; these varying citations most likely originated in runaways' natal communities.

The beauty norms and adornment practices that runaways had witnessed under enslavement also may have shaped their bead consumption patterns in freedom. At Makoroboi, an apparent preference for dark blue beads can be convincingly interpreted as evidence of some lasting coastal cultural influence on the settlement's female inhabitants. Ethnographers have pointed out that, similar to blue porcelain, blue beads have long been perceived as protective 
amulets among the Swahili (e.g., Donley-Reid 1990: 51); despite their Christian practice, Makoroboi residents may have valued these beads for similarly divine purposes when utilized in the performance of a specifically coastal conception of female identity. Makoroboi's bead assemblage strongly contrasts that of the neighboring contemporaneous Giriama homestead, Amwathoya. There, opaque dark blue beads make up only $2.9 \%$ of the overall assemblage; in addition, no translucent blue beads matching the variety at Makoroboi were recovered at all (Marshall 2011: 252).

Yet, we are far from being able to say that bead adornment at Koromio and Makoroboi was entirely dictated by the previous citations that female refugees had witnessed either under enslavement or prior to initial capture. That is, we must not neglect the roles of improvisation and individual preference in shaping the recovered assemblages. British explorer Harry Johnston warned his compatriots of the highly individualized tastes of Eastern African consumers, as "an entire tribe may affect one shade of blue in their bead necklaces, yet each individual will have special opinion as to the correct size of the bead" (Johnston 1886, 45, quoted in Prestholdt 2008: $64)$.

To understand the context in which women improvised their adornment and their motivations for doing so, it would be useful here to return to the concept of field. I now want to consider the field of gender relationships within watoro settlements themselves, where women's position may have been in some flux due in part to their low numbers. Makoroboi is remembered in oral histories as a male-heavy settlement (e.g., Ngumbao Iha, interviewed 25 October 2007; Johana Karisa Katenge, interviewed 26 October 2007). Such a gender imbalance has been observed in many Maroon settlements the world over, as men tend to be more likely to abscond from slavery (e.g., Franklin and Schweninger 1999: 210-213). This imbalance affected 
Makoroboi male residents' social position vis-à-vis women in their life. For example, watoro men who married local Giriama women had significantly reduced power as compared to Giriama grooms. As I have noted elsewhere, “A Giriama bride usually adopted the clan affiliation of her new husband and went to live with his extended family. In intermarriages with Makoroboi men, these gender expectations were largely reversed: a Makoroboi groom would most often adopt his new wife's ethnic and clan affiliations and settle at her family's homestead. . . . Most seriously, children born from such alliances 'belonged' not to their watoro father but to the head of the Giriama homestead in which he lived" (Marshall 2015, 291). How the gender imbalance affected the relationships between male and female refugees from slavery is less clear. What is clear is that social rules and expectations around gender were still in the process of being laid down.

At Makoroboi, all 22 beads were recovered from Structure 1 (Table 4) and none at all from Structure 2. Food remains and local pottery strongly suggest that both structures were domestic houses. Thus, rather than indicating a distinctive structure use, the lack of beads at Structure 2 may reveal something about its inhabitants. It is certainly possible that beads were worn by inhabitants of Structure 2 but not later recovered at the site. Yet, beads are small and easily lost items; the complete lack of beads at Structure 2 despite intensive water-screening of domestic contexts is surprising. Considering that oral histories emphasize Makoroboi's maleheavy population, the lack of beads at Structure 2 may indicate that certain households at the settlement had no women. Such a population distribution would have affected how certain gendered tasks were completed. For example, archaeobotanical evidence from the site indicates heavy dependence on maize (Marshall 2011: 366). Yet, no maize grinding equipment was found at either excavated structure, suggesting such a task may have been undertaken on a cooperative community level rather than individually by each household. In Eastern Africa, maize grinding is 
widely considered women's work, and so the lack of women at certain households may have necessitated inter-household cooperation in maize preparation. Thus, the distribution of beads and the absence of maize grinding equipment recovered at Makoroboi may suggest social improvisation and shifting gender relations as inhabitants negotiated a strong gender imbalance in their population.

The 22 beads recovered at Makoroboi's Structure 1 contrast with very low numbers of other types of imported goods. For example, only three sherds of imported pottery were recovered at the site. At Makoroboi, more than seven beads were found for every imported pottery sherd. This pattern differs from that found at Koromio, where 753 sherds of imported pottery and 79 beads were found; there, approximately one bead was recovered for every 10 pieces of imported pottery. This inter-site comparison points to a couple of interpretive conclusions. First, Makoroboi had lesser participation in external trade markets than Koromio. Yet, despite this lesser participation, the relative dominance of beads in the imported assemblage suggests that such ornaments (as expressions of femininity and beauty) may have been more valued than other types of foreign goods.

\section{Conclusion}

This article's analysis challenges us to think about gender identities and relationships even in spaces, like fugitive slave settlements, conventionally considered masculine places. It also reminds us that consumption is a powerful analytical framework, the application of which can be beneficial even in the study of disenfranchised groups. In recognizing the effects of poverty and market access, archaeologists should not discount the role of consumer choice. 
Nineteenth-century Eastern Africa was deeply embedded in global capitalism (Croucher 2015), as the presence of European imports at even semi-isolated sites like Koromio and Makoroboi attests. Clearly, bead consumption at both Makoroboi and Koromio was economically and politically constrained. Yet, the choices that runaways made within these constraints were nonetheless socially and symbolically meaningful. These choices were built in part on adornment norms derived from runaways' free natal communities as well as ideas encountered under enslavement on the coast.

Yet, bead consumption would have also provided space for female runaways' own improvisation as actors navigating gendered roles in flux. While practice theory has been of enormous value to archaeologists, its theoretical utility is truncated when accompanied by an exclusionary focus on habitus as determining practice. It is not enough to say the bead assemblages at Koromio and Makoroboi are the result of embodied practices developed under enslavement or prior to initial capture. Rather, we must also consider how female refugees from slavery would have negotiated a shifting social field. We must recognize the inherent possibility that individuals could redefine norms and practices in such nascent groups through improvisation and individual choice. By consuming and adorning themselves with particular varieties of beads, women at the fugitive slave settlements Makoroboi and Koromio performed their womanhood and affirmed their broader humanity. 


\section{Acknowledgments}

Particular thanks are due to Dr. Suzanne Spencer-Wood for her invitation to participate in the symposium "Gendering Consumer Choice" at the 2013 Annual Meeting of the Society for Historical Archaeology in Leicester, England. In the intervening years, Dr. Spencer-Wood has provided valuable critiques and guidance that materially improved this article's argument; I am grateful for her scholarly generosity. I am thankful for the advice and assistance of current and past staff at the Coastal Archaeology Division of the National Museums of Kenya, including Jambo Haro, Dr. Herman Kiriama, Ibrahim Busolo, George Ghandi, Philip Wanyama, Mohamed Mchulla Mohamed, and the late Kaingu Kalume Tinga. I am also grateful to landowners Kaingu Hanga, Nyevu Menza, Kang'ombe Nzaro Moka, and Karisa Iha Nyundo for permitting excavation at Koromio and Makoroboi. Thanks are due to Drs. Adria LaViolette, Jeffrey Hantman, Joseph Miller, and Patricia Wattenmaker for their guidance of the larger dissertation project from which this article originated. I am also very thankful to Dr. Sarah Walshaw for archaeobotanical analysis and Ogeto Mwebi and his team at the Osteology Department of the

National Museums of Kenya for faunal analysis. Thanks also to my colleagues in the Department of Sociology and Anthropology at DePauw University for their encouragement and support. A preliminary season of fieldwork in summer 2006 was funded by the Explorers Club Washington Group and the University of Virginia Graduate School of Arts and Sciences. Fieldwork in 20072008 was supported by a Fulbright-Hays Dissertation Research Abroad Fellowship (\#P022A070037), a National Science Foundation Doctoral Dissertation Research Improvement Grant (\#0733784), and an International Dissertation Research Fellowship from the Social Science Research Council. Additional funding for this project was provided by a National Science Foundation Graduate Research Fellowship and a Dissertation Completion Fellowship 
from the Andrew W. Mellon Foundation/American Council of Learned Societies Early Career Fellowship Program. Finally, I am very grateful to International Journal of Historical Archaeology editor Charles E. Orser, Jr. and three anonymous reviewers for substantively improving this manuscript. 


\section{References Cited}

Agorsah, E. K. (1995). Redefining Maroon Heritage in the New World Studies. In Gerard, R. (ed.), Proceedings of the 16th International Congress for Caribbean Archaeology, Conseil Régional de la Guadeloupe and Auditorium de la Ville de Basse Terre, Basse Terre, Guadeloupe, pp. 224-234.

Agorsah, E. K. (1997). Seaman's Valley and Maroon Material Culture in Jamaica. In Winter, J. (ed.), Proceedings of the 17th Congress of the International Association for Caribbean Archaeology, Molloy College, Rockville Centre, NY, pp. 285-299.

Agorsah, E. K. (2001). The Secrets of Maroon Heroism as Pioneer Freedom Fighters of the African Diaspora. In Agorsah, E.K. (ed.), Freedom in Black History and Culture, Arrow Point Press, Middletown, CA, pp.1-17.

Agorsah, E. K. (2003). Tracking Down the Maroons: Archaeo-Geography of Marronage in the Caribbean. In Maria, C.T. and Arévalo, M.A.G. (eds.), Proceedings of the 20th International Congress for Caribbean Archaeology, Volume 2, Museo del Hombre Dominicano and Fundación Garía Arévalo, Santo Domingo, Dominican Republic, pp. 732-742.

Allen, S.J. (1998). A 'Cultural Mosaic' at Palmares?: Grappling with the Historical Archaeology of a Seventeenth-Century Brazilian Quilombo. In Funari, P.P.A. (ed.), Cultura Material e Arqueologia Histórica, Instituto de Filosofia e Ciêcias Humanas de UNICAMP, Campinas, Brazil, pp. 141-178.

Baram, U. (2008). A Haven from Slavery on Florida's Gulf Coast: Looking for Evidence of Angola on the Manatee River. African Diaspora Archaeology Newsletter (June 2008). http://www.diaspora.uiuc.edu/news0608/news0608-4.pdf. Accessed March 18, 2016.

Barrett, W.E.H. (1911). Notes on the Customs and Beliefs of the Wa-Giriama, etc., British East Africa. Journal of the Royal Anthropological Institute of Great Britain and Ireland 41: 20-39.

Baugher, S., and Venables, R.W. (1987). Ceramics as Indicators of Status and Class in Eighteenth-Century New York. In Spencer-Wood, S.M. (ed.), Consumer Choice in Historical Archaeology, Plenum Press, New York, pp. 31-53.

Beachey, R.W. (1976). The Slave Trade of Eastern Africa: A Collection of Documents. Barnes and Noble, New York.

Beaudry, M.C. (1999). House and Household: The Archaeology of Domestic Life in Early America. In Egan, G. and Michael R.L. (eds.), Old and New Worlds, Oxbow Books, Oxford, pp. $117-126$.

Beck, H.C. (1927). Classification and Nomenclature of Beads and Pendants. Archaeologia 77: 176. 
Bianco, B.A. (1991). Women and Things: Pokot Motherhood as Political Destiny. American Ethnologist 18(4): 770-785.

Bilby, K. (1997). Swearing by the Past, Swearing to the Future: Sacred Oaths, Alliances, and Treaties among the Guianese and Jamaican Maroons. Ethnohistory 44 (4): 655-689.

Bourdieu, P. (1977). Outline of a Theory of Practice, Nice, R. (trans.). Cambridge University Press, Cambridge.

Bourdieu, P. (1990). The Logic of Practice, Nice, R. (trans.). Stanford University Press, Stanford, CA.

Bourdieu, P., and Wacquant, J.D. (1993). An Invitation to Reflexive Sociology. University of Chicago Press, Chicago.

Branstner, M.C., and Martin, T.J. (1987). Working-Class Detroit: Late Victorian Consumer Choices and Status. In Spencer-Wood, S.M. (ed.), Consumer Choice in Historical Archaeology, Plenum Press, New York, pp. 301-320.

Brantley, C. (1981). The Giriama and Colonial Resistance in Kenya, 1800-1920. University of California Press, Berkeley.

Bromber, K. (2007). Mjakazi, Mpambe, Mjoli, Suria: Female Slaves in Swahili Sources. In Campbell, G., Miers, S., Miller, J.C. (eds.), Women and Slavery: Africa and the Western Indian Ocean Island, Ohio University Press, Athens, pp. 111-127.

Burley, D.V. (1989). Function, Meaning and Context: Ambiguities in Ceramic Use by the Hivernant Metis of the Northwestern Plains. Historical Archaeology 23(1): 97-106.

Burton, R.F. (1860). The Lake Regions of Central Africa: A Picture of Exploration, Volume 1. Harper and Brothers, New York.

Butler, J. (1990). Gender Trouble: Feminism and the Subversion of Identity. Routledge, New York.

Butler, J. (1993). Bodies That Matter: On the Discursive Limits of "Sex." Routledge, New York.

Butler, J. (2004). Undoing Gender. Routledge, New York.

Carey, M. (1986). Beads and Beadwork of East and South Africa. Shire Publications, Princes Risborough, Aylesbury, Buckinghamshire, UK. 
Chowdury, A. (2003). Maroon Slave Archaeological Investigation Project in the Republic of Mauritius. Unpublished project report submitted to National Heritage Trust Fund Board, University of Mauritius, Réduit.

Cook, L.J., Yamin, R., and McCarthy, J.P. (1996). Shopping as Meaningful Action: Toward Redefinition of Consumption in Historical Archaeology. Historical Archaeology 30(4): 50-65.

Cooper, F. (1997). Plantation Slavery on the East Coast of Africa. Heinemann, Portsmouth.

Cooper, F. (1980). From Slaves to Squatters: Plantation Labor and Agriculture in Zanzibar and Coastal Kenya, 1890-1925. Yale University Press, New Haven.

Coquery-Vidrovitch, C. (2007). Women, Marriage, and Slavery in Sub-Saharan Africa in the Nineteenth Century. In Campbell, G., Miers, S., Miller, J.C. (eds.), Women and Slavery: Africa and the Western Indian Ocean Island, Ohio University Press, Athens, pp. 43-61.

Croucher, S.K. (2007). Clove Plantations on Nineteenth-Century Zanzibar: Possibilities for Gender Archaeology in Africa. Journal of Social Archaeology 7(3): 302-324.

Croucher, S.K. (2011). Exchange Values: Commodities, Colonialism and Identity on Nineteenth Century Zanzibar. In Croucher, S.K. and Weiss, L. (eds.), The Archaeology of Capitalism in Colonial Contexts: Postcolonial Historical Archaeologies, Springer, New York, pp. 165-191.

Croucher, S.K. (2015). Capitalism and Cloves: An Archaeology of Plantation Life on Nineteenth-Century Zanzibar. Springer, New York.

Deagan, K., and Landers, J. (1999). Fort Mosé: Earliest Free African-American Town in the United States. In Singleton, T.A. (ed.), "I, Too, Am America": Archaeological Studies of African-American Life, University Press of Virginia, Charlottesville, pp. 261-282.

Deutsch, J.G. (2006). Emancipation without Abolition in German East Africa, c. 1884-1914. Ohio University Press, Athens.

Deutsch, J.G. (2007). Prices for Female Slaves and Changes in Their Life Cycle: Evidence from German East Africa. In Campbell, G., Miers, S., Miller, J.C. (eds.), Women and Slavery: Africa and the Western Indian Ocean Island, Ohio University Press, Athens, pp. 129-144.

Donley-Reid, L.W. (1990). The Power of Swahili Porcelain, Beads, and Pottery. In Nelson, S.M., and Kehoe, A.N. (eds.), Powers of Observation: Alternative Views in Archaeology. Archaeological Papers of the American Anthropological Association, No. 2., American Anthropological Association, Washington, D.C., pp. 47-59. 
Dubin, L.S. (1987). The History of Beads: From 30,000 B.C. to the Present. Harry N. Abrams, New York.

Fair, L. (1998). Dressing Up: Clothes, Class, and Gender in Post-Abolition Zanzibar. Journal of African History 39(1): 63-94.

Franklin, J.H. and Schweninger L. (1999). Runaway Slaves: Rebels on the Plantation. Oxford University Press, Oxford.

Fitts, R.K. (1999). The Archaeology of Middle-Class Domesticity and Gentility in Victorian Brooklyn. Historical Archaeology 33(1): 39-63.

Galle, J.E. (2010). Costly Signaling and Gendered Social Strategies among Slaves in the $18^{\text {th }}$ Century Chesapeake. American Antiquity 75(1): 19-43.

Garrow, P.H. (1987). The Use of Converging Lines of Evidence for Determining Socioeconomic Status. In In Spencer-Wood, S.M. (ed.), Consumer Choice in Historical Archaeology, Plenum Press, New York, pp. 217-231.

Giddens, A. (1984). The Constitution of Society: Outline of the Theory of Structuration. University of California Press, Berkeley.

Gijanto, L. (2011). Personal Adornment and Expressions of Wealth: Beads and the Gambia River's Atlantic Trade. International Journal of Historical Archaeology 15(4): 637-668.

Gissing, C.E. (1884). A Journey from Mombasa to Mounts Ndara and Kasigao. Proceedings of the Royal Geographical Society and Monthly Record of Geography, New Monthly Series, 6(10): 551-566.

Glassman, J. (1991). The Bondsman's New Clothes: The Contradictory Consciousness of Slave Resistance on the Swahili Coast. Journal of African History 32(2): 277-312.

Glassman, J. (1995). Feasts and Riot: Revelry, Rebellion, and Popular Consciousness on the Swahili Coast, 1856-1888. Heinemann, Portsmouth.

Handford, J.W. (1885). The Freed Slaves at Frere Town. Church Missionary Intelligencer and Record, New Series 10(3): 158-167.

Harding, J.R. (1962). Nineteenth-Century Trade Beads in Tanganyika. Man 62: 104-106.

Harrison, R. (2007). Materiality, "Ambiguity” and the Unfamiliar in the Archaeology of InterSocietal Confrontations: A Case Study from Northwest Australia. In Cornell, P., and Fahlander, 
F. (eds.), Encounters, Materialities, Confrontations: Archaeologies of Social Space and Interaction, Cambridge Scholars, Newcastle, UK, pp. 42-57.

Heberling, P.M. (1987). Status Indicators: Another Strategy for Interpretation of Settlement Pattern in a Nineteenth-century Industrial Village. In Spencer-Wood, S.M. (ed.), Consumer Choice in Historical Archaeology, Plenum Press, New York, pp. 199-216.

Henry, S. (1991). Consumers, Commodities, and Choices: A General Model of Consumer Behavior. Historical Archaeology 25(2): 3-14.

Huelsbeck, D.R. (1991). Faunal Remains and Consumer Behavior: What is Being Measured? Historical Archaeology 25(2): 62-76.

Johnston, H. (1886). The Kilimanjaro Expedition: A Record of Scientific Exploration in Eastern Equatorial Africa. K. Paul, Trench, and Co., London

Joyce, R. (2000). "Girling the Girl and Boying the Boy: The Production of Adulthood in Ancient Mesoamerica.” World Archaeology 31(3): 473-483.

Karklins, K. (1985). Glass Beads. Studies in Archaeology, Architecture, and History. National Historic Parks and Sites Branch, Parks Canada, Environment Canada. Minister of Supplies and Services Canada, Hull, Quebec.

Karklins, K. (1992). Identifying Beads Used in the $19^{\text {th }}$-Century East Africa Trade. Beads 4: 4959.

Kassam, A., and Megersa, G. (1989). Iron and Beads: Male and Female Symbols of Creation. A Study of Ornament among Booran Oromo (East Africa). In Hodder, I. (ed.), The Meaning of Things: Material Culture and Symbolic Expression, HarperCollins, New York, pp. 23-32.

Kent, R.K. (1965). Palmares: An African State in Brazil. Journal of African History 6(2): 161175.

Kidd, K.E., and Kidd, M.A. (1970). A Classification System for Glass Beads for the Use of Field Archaeologists. Canadian Historic Sites, Occasional Papers in Archaeology and History 1: 4589.

Kirkman, J. (1974). Fort Jesus: A Portuguese Fortress on the East African Coast. Oxford University Press, Oxford.

Klein, T.H. (1991). Nineteenth Century Ceramics and Models of Consumer Behavior. Historical Archaeology 25(2): 77-91. 
Krapf, J.L. (1846a). Journal Entry, 13 March. Section IV: Africa Missions, Part 16, Reel 317 , CA5/M1: Mission Book, 1842-1846. Church Missionary Society Archive, London

Krapf, J.L. (1846b). Journal Entry, 25 February. Section IV, Part 16. Reel 317, CA5/M1: Mission Book, 1842-1846. Church Missionary Society Archives, London.

Krapf, J.L. (2002). Memoir on the East African Slave Trade. Afro-Pub, Wein.

Kusimba, C.M. (2015). The Impact of Slavery on the East African Political Economy and Gender Relationship. In Marshall, L.W. (ed.), The Archaeology of Slavery: A Comparative Approach to Captivity and Coercion, Center for Archaeological Investigations, Southern Illinois University Carbondale, Occasional Paper No. 41, Southern Illinois University Press, Carbondale, pp. 230-254.

Joyce, R.A. (2000). Girling the Girl, Boying the Boy: The Production of Adulthood in Ancient Mesoamerica. World Archaeology 31(3): 473-483.

Labelle, M.L. (2005). Beads of Life: Eastern and Southern African Beadwork from Canadian Collections. Mercury Series, Cultural Studies Paper 78. Canadian Museum of Civilization, Gatineau, Quebec.

La Rosa Corzo, G. (2003). Runaway Slave Settlements in Cuba: Resistance and Repression, Todd, M. (trans.). University of North Carolina Press, Chapel Hill.

Livingstone, D. and Livingston, C. (1865). Narrative of an Expedition to the Zambesi and its Tributaries; and of the Discovery of the Lakes Shirwa and Nyasa, 1858-1864. John Murray, London.

Mann, R. (2000). The History of Beads in East Africa. Kenya Part and Present 31: 36-47.

Marshall, L.W. (2011). Fugitive Slaves and Community Creation in 19 ${ }^{\text {th }}$-Century Kenya: An Archaeological and Historical Investigation of Watoro Villages. Doctoral dissertation, Department of Anthropology, University of Virginia. University Microfilms International, Ann Arbor, MI.

Marshall, L.W. (2012a). Typological and Interpretive Analysis of a $19^{\text {th }}$-Century Bead Cache in Coastal Kenya. Journal of African Archaeology 10(2): 189-205.

Marshall, L.W. (2012b). Spatiality and the Interpretation of Identity Formation: Fugitive Slave Community Creation in $19^{\text {th }}$-Century Kenya. African Archaeological Review 29(4): 355-381.

Marshall, L.W. (2015). Marronage and the Politics of Memory: Fugitive Slaves, Interaction, and Integration in Nineteenth-Century Kenya. In Marshall, L.W. (ed.), The Archaeology of Slavery: A Comparative Approach to Captivity and Coercion, Center for Archaeological Investigations, 
Southern Illinois University Carbondale, Occasional Paper No. 41, Southern Illinois University Press, Carbondale, pp. 276-299.

McBride, W. S., and McBride, K.A. (1987). Socioeconomic Variation in a Late Antebellum Southern Town: The View from Archaeological and Documentary Sources. In Spencer-Wood, S.M. (ed.), Consumer Choice in Historical Archaeology, Plenum Press, New York, pp. 143-161.

McMahon, E. (2015). The Value of Marriage: Missionaries, Ex-Slaves, and the Legal Debates over Marriage in Colonial Pemba Island. In Stiles, E.E., and Thompson, K.D. (eds.), Gendered Lives in the Western Indian Ocean: Islam, Marriage, and Sexuality on the Swahili Coast, Ohio University Press, Athens, pp. 60-84.

Miller, D. (1987). Material Culture and Mass Consumption. Basil Blackwell, New York.

Morton, R. F. (1976). Slaves, Fugitives, and Freedmen on the Kenya Coast, 1873-1907. Doctoral dissertation, Department of History, Syracuse University. University Microfilms International, Ann Arbor, MI.

Morton, R. F. (1978). A Reappraisal of the History of Wata Hunters of the Kenya Coast in the Pre-Colonial Era. Kenya Historical Review 6: 23-56.

Mullins, P. (1999). Race and the Genteel Consumer: Class and African-American Consumption, 1850-1930. Historical Archaeology 33(1): 22-38.

Mullins, P. (2001). Racializing the Parlor: Race and Victorian Bric-a-Brac Consumption. In Orser, C.E., Jr., Race and the Archaeology of Identity, University of Utah Press, Salt Lake City, pp. 158-176.

Mullins, P. (2011). The Archaeology of Consumption. Annual Review of Anthropology 40: 133144.

Orser, C.E., Jr. (1996). A Historical Archaeology of the Modern World. Plenum Press, New York.

Orser, C.E., Jr. (1998). Archaeology of the African Diaspora. Annual Review of Anthropology 27: 63-82.

Orser, C.E., Jr. (2004). Race and Practice in Archaeological Interpretation. University of Pennsylvania Press, Philadelphia. 
Orser, C.E., Jr. (2005). Network Theory and the Archaeology of Modern History. In Funari, P.P.A., Zarankin, A., and Stovel, E., Global Archaeological Theory: Contextual Voices and Contemporary Thoughts, Kluwer Academic/Plenum Publishers, New York, pp. 77-95.

Perry, E.M. and Joyce, R.A. (2001). Providing a Past for "Bodies That Matter": Judith Butler's Impact on the Archaeology of Gender. International Journal of Sexuality and Gender Studies 6 (1/2): 63-76.

Perry, E.M. and R.A. Joyce. (2005). Past Performance: The Archaeology of Gender as Influenced by the Work of Judith Butler. In Breen, M.S., and Blumenfeld, W.J. (eds.), Butler Matters: Judith Butler's Impact on Feminist and Queer Studies, Ashgate, Burlington, VT., 113126.

Pezzarossi, G. (2014). Camouflaging Consumption and Colonial Mimicry: The Materiality of an Eighteenth- and Nineteenth-Century Nipmuc Household. International Journal of Historical Archaeology 18(1): 146-174.

Price, W.S. (1882). Notes from East Africa. Church Missionary Gleaner 9(103): 90-92.

Richard, F.G. (2013). Thinking through "Vernacular Cosmopolitanisms": Historical Archaeology in Senegal and the Material Contours of the African Atlantic. International Journal of Historical Archaeology 17(1): 40-71.

Robertson, C.C. (1997). Gender and Trade Relations in Central Kenya in the Late Nineteenth Century. International Journal of African Historical Studies 30(1): 23-47.

Romero Curtin, P. (1983). Laboratory for the Oral History of Slavery: The Island of Lamu on the Kenya Coast. American Historical Review 88(4): 858-882.

Rotman, D.L. (2009). The Historical Archaeology of Gendered Lives. Springer, New York.

Sacleux, C. (1939). Dictionnarie Swahili-Français. Institut d'Ethnologie, Paris.

Sayers, D.O. (2007). Landscapes of Alienation: An Archaeological Report of Excursions in the Great Dismal Swamp. Transforming Anthropology 15(2): 149-157.

Sayers, D.O. (2014). A Desolate Place for a Defiant People: The Archaeology of Maroons, Indigenous Americans, and Enslaved Laborers in the Great Dismal Swamp. University Press of Florida, Gainesville.

Sheriff, Abdul M.H. (1985). The Slave Mode of Production along the East African Coast, 18101873. In Slaves and Slavery in Muslim Africa, ed. John Ralph Willis, 161-181. London: Cass. 
Sheriff, A.M.H. (1987). Slaves, Spices \& Ivory in Zanzibar: Integration of an East African Commercial Empire into the World Economy, 1770-1873. James Currey, London.

Shepard, S.J. (1987). Status Variation in Antebellum Alexandria: An Archaeological Study of Ceramic Tableware. In Spencer-Wood, S.M. (ed.), Consumer Choice in Historical Archaeology, Plenum Press, New York, pp. 163-198.

Singer, D.A. (1987). Threshold of Affordability: Assessing Fish Remains for Socioeconomics. In Spencer-Wood, S.M. (ed.), Consumer Choice in Historical Archaeology, Plenum Press, New York, pp. 85-100.

Spencer-Wood, S.M. (1987a). Introduction. In Spencer-Wood, S.M. (ed.), Consumer Choice in Historical Archaeology, Plenum Press, New York, pp. 1-24.

Spencer-Wood, S.M. (1987b). Miller's Indices and Consumer-Choice Profiles: Status-Related Behaviors in White Ceramics. In Spencer-Wood, S.M. (ed.), Consumer Choice in Historical Archaeology, Plenum Press, New York, pp. 321-358.

Spencer-Wood, S.M., and Heberling, S.D. (1987). Consumer Choices in White Ceramics: A Comparison of Eleven Early Nineteenth-Century Sites. In Spencer-Wood, S.M. (ed.), Consumer Choice in Historical Archaeology, Plenum Press, New York, pp. 55-84.

Spencer-Wood, S.M. (1996). Feminist Historical Archaeology and the Transformation of American Culture by Domestic Reform Movements, 1840-1925. In De Cunzo, L.A., and Herman, B.L. (eds.), Historical Archaeology and the Study of American Culture, Winterthur Museum and University of Tennessee Press, Knoxville, pp. 397-445

Stanley, H.M. (1872). How I Found Livingstone: Travels, Adventures, and Discoveries in Central Africa. Scribner, Armstrong, \& Co, New York.

Stanley, H.M. (1878). Through the Dark Continent, Volume 2. Harper \& Brothers Publishers, New York.

Strayer, R.W. (1973). The Dynamics of Mission Expansion: A Case Study from Kenya, 18751914. International Journal of African Historical Studies 6(2): 229-248

Stroomer, H. (1987). A Comparative Study of Three Southern Oromo Dialects in Kenya: Phonology, Morphology and Vocabulary. Helmut Buske Verlag Hamburg, Hamburg.

Sunseri, T. (1993). Slave Ransoming in German East Africa, 1885-1922. International Journal of African Historical Studies 26(3): 481-511. 
Thomson, J. (1881). To the Central African Lakes and Back: The Narrative of the Royal Geographical Society's East Central African Expedition, 1878-1880, Volume 1. Houghton, Mifflin, and Co, Boston.

Van der Sleen, W.G.N. (1973). A Handbook on Beads. L'Association Internationale pour l'Historie du Verre, Musée du Verre, Liège, Belgium.

Wall, D.d. (1991). Sacred Dinners and Secular Teas: Constructing Domesticity in Mid-19 ${ }^{\text {th }}$ Century New York. Historical Archaeology 25(4): 69-81.

Wall, D.d. (1994). The Archaeology of Gender: Separating the Spheres in Urban America. New York: Plenum.

Wall, D.d. (1999). Examining Gender, Class, and Ethnicity in Nineteenth-Century New York City. Historical Archaeology 33(1): 102-117.

Weik, T. (2004). Archaeology of the African Diaspora in Latin America. Historical Archaeology 38(1): 32-49.

Weik, T. (2009). The Role of Ethnogenesis and Organization in the Development of AfricanNative American Settlements: An African Seminole Model. International Journal of Historical Archaeology 13(2): 206-238.

Wurst, L., and McGuire, R.H. (1999). Immaculate Consumption: A Critique of the "Shop Till You Drop" School of Human Behavior. International Journal of Historical Archaeology 3(3): 191-199. 
TABLE 1: BEAD TYPES AT KOROMIO, STRUCTURE 1

\begin{tabular}{|l|l|l|l|l|l|l|l|c|}
\hline TYPE & MATERIAL & $\begin{array}{l}\text { MANUFACTURE } \\
\text { TECHNIQUE }\end{array}$ & $\begin{array}{l}\text { KIDD } \\
\text { TYPE }\end{array}$ & $\begin{array}{l}\text { HISTORICAL } \\
\text { NAME }\end{array}$ & COLOR & SHAPE & DIAPHANEITY & COUNT \\
\hline 1 & Glass & Drawn, Simple & IIa14 & Hafti & White & Short Barrel & Opaque & 23 \\
\hline 2 & Glass & Drawn, Simple & IIa12 & Dudio & White & Short Barrel & Translucent & 1 \\
\hline 3 & Glass & Drawn, Simple & IIa7 & Bubu & Black & Short Barrel & Opaque & 2 \\
\hline 4 & Glass & Drawn, Simple & IIa* & Lakio & Brown & Short Barrel & Opaque & 1 \\
\hline 5 & Glass & Drawn, Simple & Ila27 & Magio & Green & Short Barrel & Opaque & 4 \\
\hline 6 & Glass & Drawn, Simple & Ila34 & Wadiro* & Light Sky Blue & Short Barrel & Opaque & 5 \\
\hline 13 & Glass & $\begin{array}{l}\text { Drawn, } \\
\text { Compound }\end{array}$ & IVa9 & Simsim & $\begin{array}{l}\text { Scarlet } \\
\text { over White }\end{array}$ & Short Barrel & $\begin{array}{l}\text { Translucent } \\
\text { over Opaque }\end{array}$ & 4 \\
\hline 16 & Glass & Wound & WIc* & Sereketi & Dark Pink & Ellipsoid & Translucent & 1 \\
\hline 23 & Carnelian & Cut/Carved & - & - & N/a & Short Barrel & N/a & \\
\hline Total & & & & & & & & \\
\hline
\end{tabular}

TABLE 2: BEAD TYPES AT KOROMIO, STRUCTURE 2

\begin{tabular}{|c|c|c|c|c|c|c|c|c|}
\hline TYPE & MATERIAL & $\begin{array}{c}\text { MANUFACTURE } \\
\text { TECHNIQUE }\end{array}$ & $\begin{array}{l}\text { KIDD } \\
\text { TYPE }\end{array}$ & $\begin{array}{c}\text { HISTORICAL } \\
\text { NAME }\end{array}$ & COLOR & SHAPE & DIAPHANEITY & COUNT \\
\hline 1 & Glass & Drawn, Simple & IIa14 & Hafti & White & Short Barrel & Opaque & 1 \\
\hline 6 & Glass & Drawn, Simple & IIa34 & Wadiro* & $\begin{array}{l}\text { Light Sky } \\
\text { Blue }\end{array}$ & Short Barrel & Opaque & 3 \\
\hline 7 & Glass & Drawn, Simple & ПI** & Langiyo $*$ & $\begin{array}{l}\text { Bright } \\
\text { Medium } \\
\text { Blue }\end{array}$ & Short Barrel & Opaque & 11 \\
\hline 8 & Glass & Drawn, Simple & IIa* & Kikete* & $\begin{array}{l}\text { Bright } \\
\text { Turquoise }\end{array}$ & $\begin{array}{l}\text { Medium } \\
\text { Barrel }\end{array}$ & Opaque & 1 \\
\hline 9 & Glass & Drawn, Simple & IIa* & Sukoli & Orange & $\begin{array}{l}\text { Medium } \\
\text { Barrel }\end{array}$ & Opaque & 1 \\
\hline 10 & Glass & Drawn, Simple & Ia16 & - & Gray-Blue & Long Cylinder & Translucent & 1 \\
\hline 14 & Glass & $\begin{array}{l}\text { Drawn, } \\
\text { Compound }\end{array}$ & IIIa* & - & $\begin{array}{l}\text { Red } \\
\text { over Brown }\end{array}$ & $\begin{array}{l}\text { Medium } \\
\text { Cylinder }\end{array}$ & $\begin{array}{l}\text { Opaque } \\
\text { over Opaque }\end{array}$ & 1 \\
\hline 15 & Glass & $\begin{array}{l}\text { Drawn, } \\
\text { Compound }\end{array}$ & $\mathrm{IVa}^{*}$ & - & $\begin{array}{l}\text { Turquoise } \\
\text { over White }\end{array}$ & $\begin{array}{l}\text { Medium } \\
\text { Barrel }\end{array}$ & $\begin{array}{l}\text { Opaque } \\
\text { over opaque }\end{array}$ & 2 \\
\hline 17 & Glass & Wound & WIc1 & Sungomaji & White & Ellipsoid & Opaque & 2 \\
\hline 19 & Glass & Wound & WIc* & Nílí* & Green & Ellipsoid & Translucent & 2 \\
\hline 20 & Glass & Wound & WIb2 & - & White & Spheroid & Opaque & 2 \\
\hline 22 & Glass & Press-Molded & MPIa & - & Green & Short Barrel & Translucent & 1 \\
\hline Total & & & & & & & & 28 \\
\hline
\end{tabular}


TABLE 3: BEAD TYPES AT KOROMIO, STRUCTURE 3

\begin{tabular}{|l|l|l|l|l|l|l|l|c|}
\hline $\begin{array}{c}\text { TYPE } \\
\#\end{array}$ & MATERIAL & $\begin{array}{l}\text { MANUFACTURE } \\
\text { TECHNIQUE }\end{array}$ & $\begin{array}{l}\text { KIDD } \\
\text { TYPE }\end{array}$ & $\begin{array}{l}\text { HISTORICAL } \\
\text { NAME }\end{array}$ & COLOR & SHAPE & DIAPHANEITY & COUNT \\
\hline 1 & Glass & Drawn, Simple & IIa14 & Hafti & White & Short Barrel & Opaque & 2 \\
\hline 13 & Glass & $\begin{array}{l}\text { Drawn, } \\
\text { Compound }\end{array}$ & IVa9 & Simsim & $\begin{array}{l}\text { Scarlet } \\
\text { over White }\end{array}$ & Short Barrel & $\begin{array}{l}\text { Translucent } \\
\text { over Opaque }\end{array}$ & 1 \\
\hline 17 & Glass & Wound & WIc1 & Sungomaji & White & Ellipsoid & Opaque & 1 \\
\hline 18 & Glass & Wound & WIc9 & Sungomaji & $\begin{array}{l}\text { Bright } \\
\text { Medium Blue }\end{array}$ & Ellipsoid & Opaque & 2 \\
\hline Total & & & & & & & & 6 \\
\hline
\end{tabular}

TABLE 4: BEAD TYPES AT MAKOROBOI, STRUCTURE 1

\begin{tabular}{|c|c|c|c|c|c|c|c|c|}
\hline $\begin{array}{c}\text { TYPE } \\
\#\end{array}$ & MATERIAL & $\begin{array}{c}\text { MANUFACTURE } \\
\text { TECHNIQUE }\end{array}$ & $\begin{array}{l}\text { KIDD } \\
\text { TYPE }\end{array}$ & $\begin{array}{l}\text { HISTORICAL } \\
\text { NAME }\end{array}$ & COLOR & SHAPE & DIAPHANEITY & COUNT \\
\hline 1 & Glass & Drawn, Simple & IIa14 & Hafti & White & Short Barrel & Opaque & 7 \\
\hline 11 & Glass & Drawn, Simple & $\mathrm{IIa}^{*}$ & Choroko* & Dull Green & Short Barrel & Opaque & 2 \\
\hline 12 & Glass & Drawn, Simple & IIa56 & Asmani* & Dark Blue & Short Barrel & Translucent & 8 \\
\hline 13 & Glass & Drawn, Compound & IVa9 & Simsim & $\begin{array}{l}\text { Scarlet } \\
\text { over White }\end{array}$ & Short Barrel & $\begin{array}{l}\text { Translucent } \\
\text { over Opaque }\end{array}$ & 3 \\
\hline 21 & Glass & Wound & WId4 & Mzizima & Dark Blue & Oblate & Translucent & 1 \\
\hline 24 & Pewter & Cast & - & - & Silver- Black & Spheroid & $\mathrm{N} / \mathrm{a}$ & 1 \\
\hline Total & - & - & - & - & - & - & - & 22 \\
\hline
\end{tabular}

\section{FIGURE CAPTIONS}

Figure 1: Location of nineteenth-century settlements Koromio, Makoroboi, and Amwathoya (by Erin Minnick, GIS Center, DePauw University, adapted from Digital Chart of the World data, http://www.maproom.psu/dcw).

Figure 2: Identified bead types from Koromio and Makoroboi (photos and chart by author). 